University of Chicago Law School

Chicago Unbound

Journal Articles

Faculty Scholarship

1986

\title{
The Ethical Significance of Free Choice: A Reply to Professor West
}

Richard A. Posner

Follow this and additional works at: https://chicagounbound.uchicago.edu/journal_articles

Part of the Law Commons

\section{Recommended Citation}

Richard A. Posner, Response, "The Ethical Significance of Free Choice: A Reply to Professor West", 99 Harvard Law Review 1431 (1986).

This Article is brought to you for free and open access by the Faculty Scholarship at Chicago Unbound. It has been accepted for inclusion in Journal Articles by an authorized administrator of Chicago Unbound. For more information, please contact unbound@law.uchicago.edu. 


\section{COLLOQUY}

\section{THE ETHICAL SIGNIFICANCE OF FREE CHOICE: A REPLY TO PROFESSOR WEST}

\section{Richard A. Posner}

The editors have graciously invited me to reply to Professor West's article criticizing - on the basis of Franz Kafka's fiction - an ethical view that I have defended. ${ }^{1}$ As an admirer of Kafka, whom she has given me an excuse to reread and call it work, I am happy to accept the invitation. I would be happier still if her paper and this reply had been submitted to a journal of philosophy or literature rather than to the Harvard Law Review; for though I would be the last person in the world to quarrel with the application to law of insights from other disciplines, there are no applications to law in Professor West's article. But having said this, I must quickly add that I am almost too deeply flattered for words to be bracketed with Kafka in the pages of this or any other journal, as in, "For both writers [Kafka and Posner], the consequence of this central paradox is ...."2 Whether or not one agrees with W.H. Auden that Kafka is to the twentieth century what Dante was to the fourteenth, ${ }^{3}$ he is one of the deities of modern culture.

The particular target of Professor West's criticism is not some idiosyncratic view of mine; it is the fundamental tenet of classical liberalism: that the government generally should not interfere with voluntary transactions that impose no uncompensated costs on nonparties - what economists today call Pareto-superior transactions. This is not to say that every such transaction is beyond ethical reproach. But the function of Pareto superiority when conceived as a principle of political philosophy is not to provide the ultimate standard for ethical choice but merely to delimit the proper role of the state.

In some of my academic writings, I have defended under the name of "wealth maximization" 4 what many consider an extreme version of

- Judge, U.S. Court of Appeals for the Seventh Circuit; Senior Lecturer, University of Chicago Law School. Convention requires that my judicial position be acknowledged, although nothing in Professor West's article or this reply relates to my work as a judge; her criticism is confined to certain of my academic writings.

The comments of Frank Easterbrook, Richard Epstein, Richard Levy, Charlene Posner, Cass Sunstein, and Richard Weisberg on a previous draft are gratefully acknowledged.

1 West, Authority, Autonomy, and Choice: The Role of Consent in the Moral and Political Visions of Franz Kafka and Richard Posner, 99 HARv. L. Rev. 384 (I985).

2 Id. at 390.

3 See R. GRAy, Franz Kafka I (1973).

4 See R. Posner, The Economics of Justice 60-87 (I98I); Posner, Wealth Maximization Revisited, 2 Notre Dame J.L. Ethics \& PUb. Pol'y 85 (Ig85). 
classical liberalism. In particular, I have defended the proposition that transactions that raise the aggregate wealth of society are entitled to respect even if they are not Pareto-superior because there are uncompensated losers. But Professor West's attack is on mainstream liberalism, and mainstream liberalism is therefore what I shall defend here. For she is not much interested in the differences between Paretosuperior and merely wealth-maximizing transactions. Voluntary transactions are quite bad enough in her view even if everyone is compensated. This is because she thinks that our choices very often, perhaps typically, make us miserable. One might have expected her to ground this position in the literature of the social sciences. ${ }^{5}$ But instead she draws her evidence entirely from fiction, her own and Kafka's.

\section{ON READING KAFKA}

An unusually enigmatic writer, ${ }^{6}$ Kafka has frequently been pressed into the service of political causes by people not much interested in literature, who find in his writings a precocious description of the police state and other contemporary deformities. ${ }^{7}$ Professor West gives us a reduced-form version of the politically engagé Kafka; she gives us Kafka the investigative reporter for the Washington Post, writing sensitively if weirdly about such things as poverty, the exploitation of women, consumer tastes, and the perils of being an entrepreneur. She diminishes Kafka. The target of her attack is Pareto, misnamed Posner; the principal casualty, however, is Kafka.

Most readers and critics have not thought Kafka a topical writer like Zola or Dreiser, or a writer of political allegories like Swift or Orwell. ${ }^{8}$ Institutions, when depicted in Kafka's fiction, are heavily

5 Some points of entry are R. BRANDT, A THEORY OF THE GOOD AND THE RIGHT chs. 38 (1979); J. ElSTer, Sour Grapes: Studies in the SUbVersion of Rationality (I983) (especially parts 3 \& 4); Judgment UNder UnCERTAINTy: HeURIStics and Biases (D. Kahneman, P. Slovic \& A. Tversky eds. I982); and Hirshleifer, The Expanding Domain of Economics, AM. ECON. REV., Dec. 1985, at 53, 59-62 (special anniversary issue).

${ }^{6} R$. GRAY, FrANZ KAFKa (I973) is an exemplary introduction to the literary criticism of Kafka's work. The diversity of critical responses to that work is well illustrated by the essays in The Kafka Debate: New Perspectives for Our Time (A. Flores ed. 1977) [hereinafter cited as THE KAFKA DEBATE]. Other worthwhile collections of critical essays include KAFKA: A Collection of Critical Essays (R. Gray ed. I962) and the special Franz Kafka issue of Modem Fiction Studies, see 8 Mod. Fiction STUd. I (Ig62).

${ }^{7} \mathrm{See}$, e.g., Stern, The Law of The Trial, in ON KAFKa: Semi-Centenary Perspectrves 22, 30 (F. Kuna ed. 1976) ("The Trial is a prophetic - or rather an anticipatory - fictional account of both the concepts underlying national socialist legislation and the practice of its law courts.").

${ }^{8}$ From the fact that Kafka studied law and worked most of his adult life for an insurance company, it does not follow that his writing is in any essential sense about law and business, although he borrowed scenes, symbols, and vocabulary from these fields. Wallace Stevens was also a lawyer employed by an insurance company, and T.S. Eliot was a banker and later a 
refracted through the medium of a singular inner vision. The essential focus is inward, on Kafka's own mental state - and what a mental state! Tormented by feelings of guilt, inadequacy, and self-disgust, morbidly attracted to suffering and death, plagued by psychosomatic illnesses, loathing (while loving) his father, unable to bring himself to marry, Kafka would have provided a field day for Freud; more to the point, his neuroses are, as we shall see, very close to the surface of his fiction. They do not deprive that fiction of universality, but they do mark it as a literature of private feeling rather than of comment on specific social and political institutions. Ambiguous, surreal, and often unfinished, Kafka's fiction perplexes and disturbs the reader with its overlay of fantasy; its unexpected fondness for Christian symbols; its preoccupation with, and disquieting acceptance of, suffering, cruelty, and death; and its fascination with the grotesque and macabre, most pronounced in the story about a torturer who kills himself on his own torture machine ("The Penal Colony"), but also evident in the works Professor West discusses. Politics and economics, however, have to be brought in from the outside, by the tendentious reader. Or so it seems to me; for Professor West is not completely alone in interpreting Kafka's fiction as a criticism of capitalism. While some Marxist critics consign Kafka to the "cultural dung heap of reaction," others have claimed him as one of their own. ${ }^{10}$

Professor West's approach, however, seems particularly eccentric. She reads Kafka so literally that the incidents and metaphors from business and law in his fiction become its meaning. That is like reading Animal Farm as a tract on farm management. Just as (to switch the example) Gulliver's Travels is not really about being a big person in a land of little people or a little person in a land of big people, or about talking horses or islands that float in the air, so Kafka's fiction is not really about people who starve themselves for a living, sons who commit suicide at their father's direction, traveling salesmen who are fired for turning into giant insects, denials of due process, judicial delay, a torturer who kills himself with his torture machine (which goes crazy in the process), singing mice, or an introspective dog.

Of Kafka's great story "A Hunger Artist" Professor West writes: "Kafka's hunger artist is the ultimate Posnerian entrepreneur, and the

publisher, but no one supposes that Stevens's or Eliot's poetry is about law or business. "Law" in Kafka's fiction is, for the most part, not law as we think of it, a system of rules; it is malevolent whimsy, as in his marvelous parable "Before the Law," in F. KAFKA, THE COMPLETE SToRIES 3 (1971) and in chapter 9 of The Trial. Perhaps that is how American law strikes Professor West.

${ }^{9}$ Fast, The Metamorphosis, in Franz KafkA: An ANThology of MARXIST CrIticism i2 (K. Hughes ed. I98I) [hereinafter cited as ANTHoLogY].

10 See, e.g., Goldstein, Bachelors and Work: Social and Economic Conditions in "The Judgment," "The Metamorphosis" and The Trial, in The KAFKA DEBATE, supra note 6, at 147 . 
artist's audience consists of Posnerian consumers."11 Such an interpretation trivializes and disfigures an exquisite parable about people's indifference to the interior lives of strangers. The hunger artist is tormented by his inability to convince an indifferent world of his artistic integrity; they think he sneaks food on the side. Eventually his spirit is so crushed that he pretends (or perhaps comes to believe) that he fasted not because of the challenge but because he was too fastidious to eat. He dies, is buried unceremoniously, ${ }^{12}$ and is replaced in his cage by a panther, which has no interior life. "A Hunger Artist" may also be about the world's indifference to Kafka's own artistic scruples; it may, indeed, be about many things. But only superficially is it about hunger, poverty, the pitfalls of entrepreneurship, and the fickleness of consumers.

Professor West likewise finds political and economic overtones where none exists in Kafka's unfinished novel The Trial. Kafka describes an encounter involving Joseph $\mathrm{K}$. (the protagonist), the Assistant Manager of the bank where he works, and a manufacturer (one of the bank's clients). Professor West quotes this passage at length as evidence that "[a]lthough $\mathrm{K}$. suffers no physical abuse on the job, he is humiliated and dehumanized, not enriched, by his white-collar employment as Chief Clerk in a bank."13 In fact, the passage merely reflects the standing rivalry between $\mathrm{K}$. and the Assistant Manager - in which $\mathrm{K}$. gives as good as he gets. Neither here nor elsewhere in the novel is $\mathrm{K}$. shown as ground down by his job. He is a big shot at work; that is one of the ironies of the novel. The passage shows not that $\mathrm{K}$. is alienated from work, but how distracted he is from his work by his preoccupation with the mysterious "judicial" proceeding in which he has become enmeshed. This is after all a book about obsession. The passage is too long to be quoted in its entirety, but a few sentences elided by Professor West will make my point:

11 West, supra note I, at 393 .

12 Here something must be said about the perils of discussing literature in translation. The Muirs' translation, which Professor West and I use, is super; but it is, of course, not literal, and in places it jazzes up Kafka's exceedingly sober prose. An example is the burial scene from "A Hunger Artist." The Muirs' translation, quoted in West, supra note I, at 409, reads: "Well, clear this out now!' said the overseer, and they buried the hunger artist, straw and all." $A$ Hunger Artist, in F. KAFKA, supra note 8, at 277. The German is, "Nun macht aber Ordnung!' sagte der Aufseher, und man begrub den Hungerkünstler samt dem Stroh." F. KAFKA, SÄMTLICHE ERZÄHLUNGEN I7I (I970). All this means is, "Now straighten things up!' said the overseer, and the hunger artist was buried together with the straw."

${ }^{13}$ West, supra note $I$, at 396 . This is another example of the pitfalls of translation. $K$. is not a clerk in the American sense; he is erster Prokurist - an important executive (as he keeps telling the reader), as Kafka was himself. The "Assistant Manager" is the second in command (literally "Deputy Director") at the bank. 
[K.] glanced up slightly, but only slightly, when the door of the Manager's room opened [and] disclosed the Assistant Manager, a blurred figure who looked as if veiled in some kind of gauze. $\mathrm{K}$. did not seek for the cause of this apparition, but merely registered its immediate effect, which was very welcome to him. For the manufacturer at once bounded from his chair and rushed over to the Assistant Manager, though $\mathrm{K}$. could have wished him to be ten times quicker, since he was afraid the apparition might vanish again. ${ }^{14}$

Far from feeling "humiliated and dehumanized" by the Assistant Manager, $\mathrm{K}$. welcomes his interruption; he wants to be rid of the manufacturer so that he can be free to think about the trial.

If you do not read Kafka tendentiously, looking for support for one ethical or political position or another - if you abandon yourself to the fiction - you will not, I think, be inclined to draw inferences about the proper organization of society. Of course, I cannot go through all his writings here. But consider "The Judgment," in which Professor West finds another indictment of business. Georg, a young merchant who works for his father, feels guilt (only slightly tinged with Schadenfreude) about an unnamed friend who had years ago gone abroad in pursuit of business opportunities that have not turned out well. After finally deciding to invite the friend to his wedding (despite concern that the friend might be made envious), Georg is suddenly, gratuitously accused by his vicious and really quite loony father of having played the friend false all these years. Here is the father talking:

"And now that you thought you'd got him down, so far down that you could set your bottom on him and sit on him and he wouldn't move, then my fine son makes up his mind to get married!"

"Because she lifted up her skirts," his father began to flute, "because she lifted up her skirts like this, the nasty creature, . . . because she lifted her skirts like this and this you made up to her, and in order to make free with her undisturbed you have disgraced your mother's memory, betrayed your friend, and stuck your father into bed so that he can't move. But he can move, or can't he?"

And he stood up quite unsupported and kicked his legs out. His insight made him radiant. ${ }^{15}$

14 F. KAFKa, THE TrIal 146 (rev. definitive ed. I97I). Kafka apparently did not think his own job humiliating and dehumanizing, although he did consider it a distraction from his primary interest, writing. Like Stevens and Eliot, Kafka was a successful executive highly regarded by his superiors. See E. Pawel, The Nightmare of Reason: A Life of Franz KAFKA I88 (1984). I do not mean to suggest that Kafka was a complacent bourgeois. I just mean that his writing is not primarily concerned with social or political criticism and that to treat it as if it were is to distort its significance.

${ }^{15}$ The Judgment, in F. KAFKA, supra note 8 , at 77,85 . 
Eventually the father - who is still standing upright on the bed, with one hand on the ceiling to steady himself - says to his son, "I sentence you now to death by drowning!"; and Georg, "the crash with which his father fell on the bed behind him . . . still in his ears," rushes out and drowns himself. ${ }^{16}$ As he leaps from the bridge, he "called in a low voice: 'Dear parents, I have always loved you, all the same,' and let himself drop. At this moment an unending stream of traffic was just going over the bridge."17 End of story.

Because Georg's friend, a brooding omnipresence in the story, is an unsuccessful businessman, Professor West conceives the story to be about capitalist alienation. How dull! It is not, in any interesting sense, about entrepreneurs, capitalism, the petite bourgeoisie, or even suicide. If it is not about the Oedipus complex, or Kafka's relationship with his own father, or why Kafka didn't marry, ${ }^{18}$ then it is about the sense of guilt, about life's unfairness, about how people tend to accept the valuation placed on them by other people, about the dislocated "feel" of modern life to highly sensitive souls, about the indifference of others to our inner turmoil - not only the passersby on the bridge, but also Georg's friend, who knows nothing about Georg's attempt to avoid distressing him with reminders of his business failure. It is an immensely rich story. But Professor West's suggestion that Georg kills himself because of guilt over "his own self-imposed alienation from [his friend's] suffering"19 - that Kafka's main point is to condemn Georg's treatment of his friend - is merely bizarre; she has taken the father's side in the story!

Professor West does not discuss Kafka's greatest story, "The Metamorphosis," but I cannot resist. Gregor Samsa, who lives with his parents and sister (and, later, three lodgers), wakes up one morning to find that he has turned into a giant insect, something like a beetle (hard back, many legs), though the author carefully leaves it undefined. Within this grotesque and repulsive form, Gregor is unchanged. He thinks and speaks as always, only no one can understand what he says; he sounds like an insect. The family, particularly Gregor's

${ }^{16}$ Id. at $87-88$.

17 Id. at 88 .

18 In this interpretation, Kafka's worldly self (Georg, who is engaged, as Kafka was several times) dies so that Kafka's writing self (Georg's friend) can be redeemed from failure and exile. See R. Gray, Franz KaFKa 6I-65 (I973); K. Flores, The Judgment, in Franz KafKa Today 5, I2-I6 (A. Flores \& H. Swander eds. 1964). Of "The Judgment" another of Kafka's commentators writes, "Never before or after, it seems, has Freud ruled so supremely over a piece of literature." E. Heller, KAFKa 22 (I974); $c f$. C. BeRnkeimer, FlaUberT and KafKa: STUDIES IN PSYCHOPOETIC STRUCTURE I67-86 (1982) (offering another psychoanalytic interpretation of "The Judgment").

${ }^{19}$ West, supra note I, at 4IO-II. Ellis and Goldstein, neither of whom Professor West cites, offer similar interpretations. See J. ElLIS, NARRation IN THE GERMaN Nouvelle: Theory AND INTERPRETATION I88-2II (1974); Goldstein, supra note 10, at I5I-52. 
father (naturally), reacts to his transformation with disgust. For a while, the family more or less puts up with Gregor, though at one point his mother has to intervene to prevent his father from killing him. But when Gregor's untimely appearance in the living room to hear his sister play the violin alerts the lodgers to his existence, and they give notice, the family locks him up in his room. In the usual style of Kafka's protagonists, Gregor - dutiful, considerate, docile, and devoted to his parents and sister whom indeed he has supported from his salesman's income - acquiesces in his family's unfeeling treatment of him and dies unshaken in his love for them. Relieved by his death, they make all sorts of new plans and celebrate with a tram ride into the country. "And it was like a confirmation of their new dreams and excellent intentions that at the end of their journey their daughter sprang to her feet first and stretched her young body." 20

Money figures in the story, and there is a striking scene, at once hilarious and horrifying, in which Gregor, in an unsuccessful effort to save his job, crawls toward his boss while delivering an intricate (but unintelligible) apology for being late to work. But it is not essentially a story about money, the job market, or any of the other things that Professor West thinks Kafka is about. ${ }^{21}$ It is about many of the same things as "The Judgment" and "A Hunger Artist," notably the gap between how we perceive ourselves and how others perceive us. Gregor accepts notionally the fact that he is an embarrassment to his family and does not resist being locked up; indeed, he expires by a kind of inanition that seems brought on by awareness that he is a burden on the family. But he cannot see himself through their eyes and in his heart of hearts cannot accept his altered appearance. To himself, he is the same old Gregor.

We all have Gregor's problem, though fortunately in less acute form. We can never make our aspirations fully understood or quite

20 The Metamorphosis, in F. KAFKA, supra note 8, at 89, 139 .

21 Goldstein offers a Marxist interpretation of the story, but one impossible to take seriously. She writes:

Gregor awakens one morning to find himself metamorphosed into a giant bug. In a sense, he actually accomplished with this event what he had long desired - he is free of work and of bosses who exploited him, he won't exhaust himself in incessant traveling, he retains his isolation and need not even struggle to maintain it. He becomes a parasite, which is merely the obverse of his former situation of maintaining others as parasites $\ldots$

$\ldots$

... Only when he is completely divorced from the entire economic and social system, after he has been wounded several times and is incapacitated - crippled, blinded and in terrible pain - only then did Gregor rid himself of senseless clock-watching, thoughts of chasing trains, worrying about family finances and his own job.

Goldstein, supra note 10, at 156,159 . (Anyone reading this who has trouble waking up mornings when the alarm clock goes off, be warned!) For an even more elaborate, but more soberly written, Marxist interpretation of the story, see Sokel, From Marx to Myth: The Structure and Function of Self-Alienation in Kafka's Metamorphosis, 26 Literary Rev. 485 (I983). 
bring our self-conception into phase with the conception that others have of us. And looking at Gregor from the other side, from the family's side, we can never completely get past the externals and enter the interior life of another person. Life goes on - the awakening love life of Gregor's sister, the life of the carnival managers and customers in "A Hunger Artist" and of the passersby in "The Judgment" - with shocking indifference to the inner life of our fellow man. The other characters in "The Metamorphosis" - the members of Gregor's family, the charwoman, the clerk, and the lodgers - are depicted not just as ordinary people but more particularly as nonneurotic people, defined (and faintly derided) as people without an interior, like the panther in a "A Hunger Artist," and juxtaposed against the neurotic with his rich, tormented, and despairing inner self. The healthy animal spirits of Gregor's sister and of the panther in "A Hunger Artist" are set against the miserable introspection of Gregor and the hunger artist. Gregor's horrible outward form symbolizes (among many other things, I am sure) the barriers created by differences in personality.

The continuity between the stories and fragments that Professor West discusses and "The Metamorphosis" suggests the superficiality of emphasizing voluntary transactions in Kafka's fiction. The transactional element in Kafka is adventitious. What happens to Gregor is neither voluntary nor transactional. The torture machine in "The Penal Colony" is not a capitalist device either, nor is the arrest of Joseph K. on unspecified charges. Professor West has not come near the nerve of Kafka's work.

\section{ON FREEdom AND Consent}

A.

But now assume with Professor West that Kafka's works should be read literally, as tracts on entrepreneurship, suicide, and so forth. When read so, what do they tell us about the ethical significance of free choice in our society? They are not realistic; read literally they provide as much insight into American life in the I980s as would Dracula or The Cask of Amontillado. Maybe Professor West's point is an ironic one - that economists have so unrealistic a conception of human nature that even the literal Kafka, the Kafka who is "Kafkaesque," is more realistic. Even Kafka's strangest characters (the officer in "The Penal Colony," for example) have a more recognizably human personality than a calculating machine. Thieves, spouses, litigants, pedestrians, trespassers, rescuers, and other nonmarket ac- 
tors encountered in economics ${ }^{22}$ do not consciously engage in costbenefit analysis. But neither do consumers consciously maximize consumer surplus, nor businessmen consciously equate marginal revenue to marginal cost. Rational choice in economics does not mean selfconsciously economic choice, or even conscious choice. Economics does not seek to depict states of mind; ${ }^{23}$ it is concerned with what people (even animals) ${ }^{24}$ do, not what they feel or think. To complain that economics does not paint a realistic picture of the conscious mind is to miss the point of economics, just as to treat Kafka as a realist is to miss the point of Kafka.

\section{B.}

But forget all this and assume that Professor West has presented a gallery of real-life examples of people transacting. We are now far from any real engagement with Kafka's fiction. We are now misusing that fiction as a journalistic account of real transactions. This is reductionism with a vengeance, but it is Professor West's method, and let us see where it leads.

She groups all of her illustrations together under the rubric of voluntary transactions that make people worse off. This procedure conflates morally dissimilar ways in which an ostensibly voluntary transaction can disappoint one or both of the parties. Some of her transactions are not wealth maximizing. Others are, and increase happiness ex ante, but turn out badly because of people's inability to predict and control the future. A third set seems completely unproblematic.

$I$. In the first group are West's bulimic tomato consumer ${ }^{25}$ and Kafka's hunger artist, who (at the literal plane to which Professor West confines Kafka) is anorexic. Bulimia and anorexia are serious psychiatric conditions. A bulimic or anorexic person cannot be presumed to be making choices that maximize his (or more commonly, her) satisfactions; nor can a person who would commit suicide because his father said to him, "I sentence you now to death by drowning." Economists do not presume that choices made by mentally incompetent people are value maximizing. But let us not be too quick to

22 I use "economics" in its broadest sense, as the science of rational choice, so that it includes nonmarket as well as market behavior. See, e.g., G. BECKER, ThE ECONOMIC APproACH to Human Behavior 5 (I976); R. POSNer, supra note 5, at $\mathrm{x}$; Hirshleifer, supra note 4, at 53.

${ }^{23}$ See, e.g., R. POSNER, supra note 4, at 204 n.72.

24 See, e.g., Kagel, Battalio, Rachlin, Green, Bassman \& Klemm, Experimental Studies of Consumer Demand Behavior Using Laboratory Animals, 13 EcoN. INQUIRY 22 (1975).

25 Professor West describes a woman who "on a daily basis . . . buys twelve tomatoes, eats five plates of spaghetti, and regurgitates it all, thus destroying her digestive tract." West, supro note $I$, at $40 \mathrm{I}$. The purpose of this example is to show that even the simplest consumer transaction is fraught with potential for disaster. 
pronounce people who make odd or even self-destructive choices incompetent. Who among us would like to be ruled by people who thought that the administration of an insane asylum provided a model for governing the United States? We know what the Soviet Union has done with an expansive definition of mental illness. The impersonality of market transactions protects privacy and freedom. Professor West and I do not have to undergo a psychiatric examination before we can buy a tomato.

Market failure of a kind different from that due to a consumer's mental incompetence is illustrated in Professor West's article by a woman's yielding to the sexual advances of a man who has power over her husband's career. ${ }^{26}$ Actually, Professor West has misunderstood the incident in The Trial between $\mathrm{K}$. and the washerwoman. The woman is talking with $\mathrm{K}$. when she sees a law student (!), who she says may some day be a big shot. She goes over to the student, who begins kissing her. $K$. intervenes, but the student picks the woman up bodily and makes off with her. $\mathrm{K}$. is about to attack the student (he does in fact rabbit-punch him) when the woman tells him to desist because the student is only obeying the orders of the Examining Magistrate. The student, puffing with fatigue, carries her up the stairway of a tenement.

The woman waved her hand to $\mathrm{K}$. as he stood below, and shrugged her shoulders to suggest that she was not to blame for this abduction, but very little regret could be read into that dumb show. . . . He was forced to the conclusion that the woman not only had betrayed him, but also had lied in saying that she was being carried to the Examining Magistrate. The Examining Magistrate surely could not be sitting waiting in a garret. ${ }^{27}$

This passage depicts not the exploitation of women but a mordant reverie about desire and diffidence. $K$. would like to believe that in yielding to the law student the woman is acting under compulsion, but he gradually realizes that this is not true, that the student and she are playing with him. (Notice also that K., not the woman or her husband, is depicted as the victim in this episode.) Most of the compulsion in The Trial is inside K.'s head. ${ }^{28}$

${ }^{26}$ See West, supra note I, at 397-99. Professor West draws her illustration from a scene in The Trial.

${ }^{27}$ F. KAFKA, supra note 14, at 70. This scene, which Professor West thinks shows Kafka's sensitivity to the problem of exploitation of women, is, curiously enough, Exhibit $A$ in a feminist denunciation of Kafka for insensitivity to the problem. See Beck, Kafka's Traffic in Women: Gender, Power, and Sexuality, 26 LITERARY Rev. 565, 569-70 (1983).

${ }^{28}$ See, e.g., R. GRAY, Franz KAFKa ch. 7 (1973); Weisberg, Avoiding Central Realities: Narrative Terror and the Failure of French Culture Under the Occupation, 5 HuM. RTS. Q. I5I, I58-60 (1983).

The "Whipper" scene in The Trial, which Professor West interprets as a commentary on 
But forget all this and suppose that Kafka really is talking about sexual harassment by supervisory employees. Such harassment (whether of a female worker or, as in The Trial, of a male worker's wife) is not efficient; it is a market failure caused by what economists call "agency costs." It reduces the output of both worker and supervisor; it also forces the employer to pay higher wages to workers to compensate them for the unpleasantness of the workplace, much as employers are forced to pay higher wages to workers to compensate them for risks of illness or injury. ${ }^{29}$ The employer might conceivably be able to pay the supervisors less, by giving them in lieu of some wages a license to harass female workers. But as there are fewer supervisors than workers, a pay cut is unlikely to compensate the employer for the higher wages he must pay the workers, and even less likely to compensate the employer for the lessened productivity of supervisors and workers who spend their time making and fending off (or yielding to) sexual advances rather than working.

Sexual harassment exists in the workplace not because it is a consensual practice - it is doubly nonconsensual, being involuntary on the woman's part (as the word "harassment" connotes) and imposing uncompensated costs on the employer - but because it is hard in practice to tell apart from ordinary flirtations between co-workers. The costs to the employer of distinguishing between these externally similar forms of behavior may exceed the benefits in lower wages and greater productivity. This fact does not make it a voluntary valuemaximizing practice; the practice is a market abuse, whether or not one worth trying to stamp out. Stealing from one's employer is not a voluntary transaction, even if the employer is unable to prevent it; neither is sexually harassing a co-worker.

Professor West says that "most of what happens to Kafka's fictional characters is fully consensual." 30 But a decision made under the

employment relations, see West, supra note $\mathrm{X}$, at $395-96$, is nothing of the sort. Joseph $\mathrm{K}$. opens the door to a storage room in his bank, and there are the two "warders" who had arrested him, being whipped for having stolen his underwear during the arrest. See KAFKA, supra note 14, at 6, 95-96. The scene, not fully quoted by Professor West, reeks of sadomasochism. The employment context seems wholly incidental. Note in particular the odd circumstance that the warders are being whipped not at their place of business but in K.'s bank. He is thereby made to feel somehow complicit in the whipping. For good discussions see R. GRAY, supra, at II2I3, and Sussman, The Court as Text: Inversion, Supplanting, and Derangement in Kafka's Der Prozess, 92 Proc. Mod. LANG. A. 4I, 43 (I977).

29 That workers demand and receive wage premia for assuming risks of physical injury or death is empirically well established. See, e.g., W.K. VIScusI, RISK By ChoICE: Regulating Health AND SafeTy IN the WorkPlace 37 (1983); Olson, An Analysis of Wage Differentials Received by Workers on Dangerous Jobs, I6 J. HuM. Resources I67 (1982); Thaler \& Rosen, The Value of Saving a Life: Evidence from the Labor Market, in HouSEHOLd PRODUCTION AND Consumption 265, 266 (N. Terleckyj ed. I975).

30 West, supra note I, at 390 . She was not thinking about Gregor Samsa when she wrote this. 
influence of a mental disease is not fully consensual; nor is the extortion of sexual favors. Among the "fully consensual" transactions listed in the conclusion to Professor West's article, ${ }^{31}$ many are not consensual at all, and some would be consensual only if there were compensation, and we are not told whether there is compensation. By definition, a woman does not consent to rape; but whether a worker consents to work in a dangerous environment depends on whether he is paid to do so $^{32}$ or tricked into doing so (the dangers may be concealed). Economic analysis of fraud and duress does not treat fraudulent or coerced choices as fully consensual; far from denying that fraud, duress, incapacity, and sometimes mistake should be defenses to suits to enforce contracts, economic analysis emphasizes that such defenses are necessary to prevent inefficient transactions from being enforced. ${ }^{33}$ Professor West has merely shown that involuntary transactions are indeed involuntary, and obviously it does not follow that voluntary transactions are involuntary as well.

2. The second category of situations that Professor West uses to argue against the ethical significance of consensual transactions involves the hard or risky choice, illustrated by the plight of the homosexual who continues to patronize homosexual bathhouses despite a high risk of contracting a fatal disease. Unless a person who takes such grave risks is deemed to be mentally ill, the homosexual in her example is merely someone put to an unhappy choice: life-style or life expectancy. Professor West may believe that because the sex drive is instinctual, no choice that it influences can be a free one. But most human choices are determined by preferences that have their roots in instinct - the instinct to survive, the instinct to reproduce. To repeat what I said earlier, I do not argue that every consensual transaction between informed adults having no effects on third parties should receive our moral approbation. The only issue is whether it should be free from government interference. If any choice rooted in our "animal instincts" is on that account to invite government intervention, then Professor West must conceive the problem of political governance as analogous to the governance of a zoo as well as to that of an insane asylum.

The example of the bathhouse is in one aspect merely a dramatic illustration of choice under uncertainty - choice that has the property that it may turn out badly. I wonder what Professor West would say about the following choice. A spinal fusion operation intended to alleviate the often agonizing and disabling pain from spinal disc disease carries with it a significant risk of causing paralysis. Should a patient who is fully informed of the risk and the possible benefits of

31 See id. at 427 .

32 See supra note 29.

${ }^{33}$ See, e.g., R. POSNER, Economic ANalysis of LAW 87-88, 90-9I, 96-I05 (3d ed. I986). 
the operation be forbidden to give his or her consent to it, because it is a choice made under uncertainty? If the patient, coerced by pain as it were, chooses the operation and becomes paralyzed, does that show that the patient lacked freedom of choice? That such choices should be reserved to physicians or to the state? That risky operations should be forbidden altogether so that the occasion for choice does not arise?

Choice under uncertainty pervades our lives. The "hunger artist" (if the story is read literally, as it should not be) failed to predict consumer preference correctly and found himself displaced by a panther, just as a comedian might find himself displaced in popular favor by a talking donkey or an animated mouse. What is arresting about Kafka's example is precisely its unrealistic premise that there is a market for watching a person starve ${ }^{34}$ In a figurative sense, every failed entrepreneur "starves"; but if he chose entrepreneurship with his eyes open, why should we feel sorry for him?35

As part of a general dislike for risk taking, Professor West is too hard on people who buy lottery tickets, literal or figurative. Suppose I were a farmer who didn't want to take the risk of price fluctuation, and therefore wanted to sell my crop for a fixed price before it was harvested. In other words, I wanted to hedge. To do so I would have to find someone willing to speculate. The more someone likes risk, the less he will charge me to bear it; he may even pay me to shift the risk of price fluctuation to him. So speculation is not, as Professor West supposes, a socially sterile activity. It facilitates hedging. It also reduces uncertainty about values by bringing more people into the market - speculators, as well as producers and consumers. Market price may not be a good predictor of market value if the market is very thin.

More important than the social benefits of risk taking is the fact that most risk is compensated. The risk one takes when one buys a lottery ticket is not compensated, because the cost of the ticket exceeds

34 Not completely unrealistic, though: there were some "hunger artists" in Kafka's day, and even later. See M. SpanN, Franz Kafka igi n.i (I976).

35 Not that Kafka meant us just to feel sorry for the hunger artist. We are meant, I am sure, to take the part both of the protagonist and of the other characters, and thus in "The Metamorphosis," for example, to see Gregor from his standpoint and from his family's standpoint - to feel sorry for him and disgusted by him. We are meant to feel for the hunger artist and to laugh at him. Kafka's art is affecting but not sentimental.

A question for Professor West: Suppose Joseph $\mathrm{K}$. had a choice between two similar jobs, in two different cities. He takes one, and years later is killed in an auto accident. The accident rate is the same in the two cities, and the jobs require the same amount of driving; but of course if he had taken the other job, the chances are very small that he would have been involved in a fatal accident. Does this show that $\mathrm{K}$. made a bad choice? If it does not show that, doesn't this mean that the ex ante perspective is, normally anyway, the correct perspective in which to evaluate choices made under uncertainty? 
the expected payoff (the prize if you win multiplied by the probability of winning). Thus, lotteries appeal only to risk preferrers. But the risk that one takes when one buys stock in a highly leveraged company, commits oneself to a risky career such as acting, or marries someone whose qualities one is not sure about is compensated risk; one engages in it only because the net expected payoff is positive. ${ }^{36}$ Of course, after the fact one may be sorely disappointed; that is the risk that was assumed. But if the choice was a good choice ex ante, we should not be forced to listen sympathetically to bellyaching ex post.

Another hard choice is the choice between the lesser of two evils. That is also a characteristic of some choices under uncertainty, as we saw; but here I want to abstract from the element of uncertainty. Professor West remarks that a job can still be a bad job even though the worker is not a slave. That is true. But if a person lacks highly marketable skills, his range of job choices is narrowed; the best job he can get may be much inferior to the jobs of other workers. The feasible set of choices is always limited, but it does not follow that people should not be allowed to make choices within their feasible set, or that the choices they make lack ethical significance merely because other people have larger feasible sets. Notice also that the wealthier the society is, the larger the feasible set is for most people. Wealth promotes freedom. ${ }^{37}$

To take another of Professor West's examples, in our society a wife does not have to take abuse, mental or physical, from her husband; she can leave him. If she stays, it may be because, all things considered, the feasible alternatives are even worse. I do not mean to condone coercion, but only to point out that freedom is not Utopia and will not prevent the dietary disorders and "bad sex" 38 that loom

${ }^{36}$ For some evidence from the marriage, securities, and job markets, respectively, see G. Becker, A Treatise on the Family chs. 3-4 (Ig8r); J. LoRie, P. Dodd \& M. Kimpton, The Stock MARKET: Theories and Evidence chs. 8 \& 9 (2d ed. 1985); and Abowd \& Ashenfelter, Anticipated Unemployment, Temporary Layoffs, and Compensating Wage Differentials, in STUdies IN LABOR MARKETS I4I (S. Rosen ed. I98I).

37 See Stigler, Wealth, and Possibly Liberty, 7 J. LEGAL STud. 2I3, 214 (1978).

38 West, supra note I, at 399 - better described, however, by Eliot than by Kafka, in the typist passage from "The Waste Land":

$\mathrm{He}$, the young man carbuncular, arrives,

A small house agent's clerk, with one bold stare,

One of the low on whom assurance sits

As a silk hat on a Bradford millionaire.

The time is now propitious, as he guesses,

The meal is ended, she is bored and tired,

Endeavors to engage her in caresses

Which still are unreproved, if undesired.

Flushed and decided, he assaults at once;

Exploring hands encounter no defence; 
large in Professor West's redaction of Kafka's fictional world. We ought to be wary about embracing a system in which government breaks up families to protect wives against themselves.

Somewhere in between the incompetent choice of the mentally ill person and the merely hard choice is the perplexing case of addiction. An alcoholic surrenders an important part of his freedom and, it might seem, gets little in return. Yet forcibly to prevent people from becoming alcoholics would infringe their freedom to choose a particular, if to the sober a disagreeable, mode of life. If the "choice" to become an alcoholic, or more realistically the assumption of the risk of alcoholism, is made on incomplete information or involves uncompensated costs to third parties (for example, in the form of accidents caused by drunk driving), then it is not a "free" choice in the Pareto-superior sense; and perhaps that is the typical case of addiction. But the mere fact that it is a choice to pursue an unfree type of life does not make the choice unfree.

3. Professor West finds problematic much easier choices than those discussed thus far. The easiest choices are hard in Professor West's version of Kafka's fictive world, because its denizens do not like to make choices; they crave submission to authority. If this is what most Americans want, we shall have to rethink our national commitment to free markets and popular government. But, as it happens, the characters in Kafka's fiction are not typical I980s Americans. Reflecting their creator's deep neuroticism and his particular historical situation as a German-speaking Czech Jew living in Prague during the twilight of the Austro-Hungarian Empire, during World War I and its turbulent aftermath, and during the early years of the Czechoslovakian republic (Kafka died in I924), Kafka's characters are marked by an extraordinary submissiveness. ${ }^{39}$ There is some point to Edmund Wilson's dictum that Kafka "is quite true to his time and place, but it is surely a time and place in which few of us will want to linger."40

His vanity requires no response,

And makes a welcome of indifference.

...

Bestow's one final patronising kiss,

And gropes his way, finding the stairs unlit

-..

She turns and looks a moment in the glass,

Hardly aware of her departed lover;

Her brain allows one half-formed thought to pass:

'Well now that's done: and I'm glad it's over.'

T.S. Eliot, The Waste Land, in Collected Poems 1909-1962, at 51, 62 (1963).

39 This submissiveness is wonderfully illustrated not only by Georg Bendemann, Gregor Samsa, and Joseph K., but also by the unnamed protagonist of the parable "Before the Law," supra note 8.

40 Wilson, $A$ Dissenting Opinion on $K a f k a$, in Kafka: A Collection of Critical Essays, supra note 6 , at $9 \mathrm{I}, 96$. 
In finding submission everywhere, Professor West confuses the desire to surrender the power of choice over the essential conditions of one's life with the decision to submit to partial and temporary direction or instruction by others. She considers both types of decision inconsistent with the ethic of free choice that I defend. But the second type surely is not. One submits to hierarchical direction by going to work for a company, rather than remaining an independent contractor, only if one's expected welfare is higher as an employee than as an independent contractor. The status is freely chosen and the choice is not irrevocable. There is no surrender of essential autonomy. Similarly, by deciding to take piano lessons I do not surrender my freedom to choose. Instruction is not coercion; the educated person has more rather than less freedom than the uneducated person. One also has more rather than less freedom if one is allowed to make legally binding contracts, even though by doing so one surrenders some freedom while the contract is in force. If I make a legally binding commitment to pay a builder to build a house for me, I enlarge my freedom; without the commitment I could not get the house built unless I paid for it first. ${ }^{41}$

\section{C.}

Someone trying to decide whether to reject the ethic of free choice might want to know what Professor West proposes to put in its place. She does not say. Although there are many unhappy and neurotic people, many unlucky people, many stupid people, many people who are prone to self-deception and wishful thinking, and many lunatics, she has no suggestions for reducing the number of these unfortunates. She also does not discuss whether enough people are seriously incompetent at coping with the challenges of life in a free society to justify making society less free and whether we can estimate the number of such people from Kafka's works.

Professor West's skepticism about choices made in market settings suggests that she may prefer a system in which more choices are made politically: she seems, after all, not averse to politicizing literature. But she does not argue the case for such a system, and the history and current practice of socialism do not make the case for her. It does not follow that because many people make some bad choices, most people would be better off if they were forbidden to make as many choices. The choices would still be made, but by politicians rather than by the individuals directly affected.

Professor West may not understand how hard it is to get from here to Utopia. She is concerned, for example, about the plight of

41 This is another point emphasized in economic analysis of law. See R. POSNER, supra note 33 , at $79-8 \mathrm{r}, 86$. 
the failed entrepreneur. But she seems not to realize that if society commits itself to bail him out - whether he is Joe Schmo, Chrysler, Lockheed, or the Continental Illinois National Bank - it encourages risky behavior, which is what Professor West dislikes, by reducing the penalties for risk. The problems of many of the people whose freedom of choice she questions, notably the promiscuous homosexual and the bulimic consumer, have nothing to do with poverty and therefore could not be solved by a redistribution of wealth, the current socialist panacea. It is not much use saying things are bad without being able to say how they can be made better.

Professor West is worried about the state's doing too much as well as too little. She is worried that an ethic of consent could be used to legitimize authoritarianism, because Kafka's fictional characters suggest to her that people may be willing to surrender their freedom of political choice forever - in much the same way that a person who signs a contract constrains some of his choices for a limited time. Put aside the fact that government in Kafka is metaphor rather than actuality, ${ }^{42}$ and notice the pickle in which Professor West's analysis puts her: if consent is ethically significant, then authoritarian government is legitimate if consented to; if consent is not ethically significant, then an authoritarian government that suppresses freedom cannot be criticized on that account. The simplest way out of the dilemma is to recognize that most people do not want an authoritarian government. They fear the consequences of a monopoly of political power. This fear animated the original design of our government and continues strong today. (World War II drove the point home for Europeans.) If Professor West believes that Americans have the same desire to be ruled with an iron hand as that expressed by some of Kafka's fictitious characters - if she believes that we have "cravings for judgment and punishment by noble authority" 43 - if she believes that the citizens of the freest society in the history of the world are "attracted to the

\footnotetext{
42 Reading The Trial, for example, you cannot believe that the "court" - with its rickety tenements, erotic overtones, and functionaries with funny clothes - has much to do with government, notwithstanding Kafka's borrowings of many details of Austro-Hungarian criminal procedure, on which see Robinson, The Law of the State in Kafka's The Trial, 6 AM. LEGAL STUD. A. FoRUM 127, 128-29 (1982). "Are you officers of the law? None of you has a uniform, unless your suit' - here he turned to Franz - 'is to be considered a uniform, but it's more like a tourist's outfit." F. KAFKA, supra note 14 , at 18 ; see id. at 4 . The "court" and its entourage are unquestionably sinister, but what the court is - the projection of Kafka's sense of guilt, a metaphor of parental tyranny, anxiety, death, despair, Fate, God, or Satan - is wholly unclear. For a good discussion, see Lesser, The Source of Guilt and the Sense of Guilt - Kafka's The Trial, 8 Mod. Fiction STud. 44, 48 (Ig62). It seems nothing so wordly as an organ of state power. From a lawyer's standpoint, the best thing in The Trial is the satire of Joseph K.'s lawyer, Huld, in chapters 7 and 8. Professor West does not discuss this part of The Trial.

${ }^{43}$ West, supra note I, at 422.
} 
authoritarian structure of law,"44 to "the authoritarian structure of fate," 45 and to "the power and punitive authority of the state"46 - if our world, like Kafka's, "is peopled by excessively authoritarian personalities"47 — then I see why she is troubled by a philosophy that assumes that people are on the whole competent judges of their selfinterest. But if she believes these things, she lives in a different world from yours and mine.

\footnotetext{
$44 I d$. at 423 .

$45 \mathrm{Id}$.

$46 I d$. at 424.

$47 I d$. at 387 .
} 